\title{
The effect of milking frequency and intervals on milk production and functional properties of the cows' udder in automatic milking systems
}

\author{
Delyus Sharipov*, Rubin Kayumov, Takhir Akhmetov, Rustam Ravilov, and Firaya Akhmetzyanova \\ Kazan State Academy of Veterinary Medicine named after N.E. Bauman, 420029 Kazan, Russia
}

\begin{abstract}
The objective of this study was to describe the association between the milking frequency and milk production and to determine the effect of milking intervals on the functional properties of the udder of cows in automatic milking systems. Thousand eight milking recordings were enrolled in the study, in total, 106 Holstein cows were observed. The results of studies showed that at a daily milk yield per cow of $22.0 \pm 0.6$ (means $\pm \mathrm{SD}$ ) $\mathrm{kg}$, the milking frequency was 2 times $(13.5 \%$ of the total number of milkings), $32.7 \pm 0.4 \mathrm{~kg}-3$ times $(57.2 \%), 37.7 \pm 0.6 \mathrm{~kg}-4$ times $(28.0 \%), 51.3 \pm 4.1 \mathrm{~kg}-5$ times $(1.3 \%)$. An increase in the daily milk yield due to a reduction in the milking interval has been established $(\mathrm{P}<0.001)$. However, milk yield per milking has the opposite tendency $(\mathrm{P}<0.001)$. The average and maximum milk flow rates increased with an increase in the milking interval and reached the highest values in the interval of $7.50-8.99$ hours -2.36 and $3.36 \mathrm{~kg} / \mathrm{min}$, respectively $(\mathrm{P}<0.001)$. Cows with a low indicator of maximum milk flow rate $(3.01 \pm 0.06 \mathrm{~kg} / \mathrm{min})$ had greater milk production $(36.6 \pm 0.47 \mathrm{~kg})$. With an increase in the milking interval from 4.50-5.99 to 7.50-8.99 hours, it was accompanied by a decrease in the latency period milk flow in the quarters of the udder, when the milking interval reached 9.00-10.49 and 10.50-11.99 hours, the latency period milk flow increased.
\end{abstract}

\section{Introduction}

The first automatic milking systems (AMS) were introduced in Europe more than 25 years ago. Since then, the number of AMS-enabled dairy enterprises has grown worldwide and there are now approximately 38,000 individual AMS units worldwide [1]. Applying the AMS the procedure of milking cows cardinally differs from milking with traditional milking equipment; cows can visit AMS at any time during 24 hours [2-4]. Many studies have been conducted in this area. Various aspects of AMS technology and its effect on milk quality, herd health, welfare, behavior, and management were examined. While using AMS, the milking process takes place without human intervention. Cows independently choose the milking time, the frequency of which is set by the animals themselves, depending on the physiological condition [5, 6].

In the Russian Federation, interest in AMS began to show in the last 10 years. The first AMS was introduced in December 2007 and by the end of 2018, nearly 1,000 AMS were already operating.

The motivations for installing an AMS can be different. The researchers note 5 main motivations for the farmers to invest in an AMS rather than in a conventional milking system: less labor, increased flexibility, the possibility of milking the cows more than twice daily, replacing an employee, or the need for a new milking system [7]. However, as with any other investment, it is crucial to optimize the efficiency of the machine to recoup the costs of the system early. The AMS is operational 24 hours a day, 7 days a week, which allows the time available for milking to be used for observation of the herd and improvement of all factors required to increase farm profitability. AMS make herd management flexible by giving freedom to organize the day without the need for fixed milking hours.

Maximum return on the investment of an AMS is attained, in theory, when cows adapt their own daily routine and traffic around the system resulting in full utilization of the AMS with little or no human intervention. Therefore, the technological properties of dairy cows are important functional features and determine the adaptation of dairy animals to AMS. Milk yield, milking frequency, milking interval, teat-cup attachment success rate, and duration of the milking procedure are important functional aspects of an AMS [8]. The milking capacity of an AMS is often expressed as the number of milkings per day, but other criteria should be considered such as average milk flow rate, maximum milk flow rate, the interval from the beginning of udder teat stimulation until the onset of milk ejection.

The objective of the study was to describe the association between the milking frequency and milk production and to determine the effect of milking

\footnotetext{
* Corresponding author: abdu10401@ rambler.ru
} 
intervals on the functional properties of the udder of cows in AMS.

\section{Material and methods}

The data used in this study were obtained from the "Mukhametshin Z.Z." farm in the Republic of Tatarstan, a dairy robotic farm with Holstein cows. On this farm, 2 groups approximately 115 lactating cows in each group were placed in separate sections. Husbandry conditions were similar for all cows.

Cows from each group were milked with 2 a one-box AMS (Astronaut A4, Lely Industries N.V., Maassluis, the Netherlands). The vacuum level was $48 \mathrm{kPa}$ and the pulsation ratio was 65:35. The cows received 1 to $9 \mathrm{~kg}$ of concentrates during milking, depending on their milk productivity, containing $1186.0 \mathrm{VEM} / \mathrm{kg}$ of dry matter (DM) and $18.4 \%$ crude protein $(\mathrm{CP})$

All cows had free access to the AMS $22 \mathrm{~h} / \mathrm{d}$ (in total 2 hours was dedicated to the cleaning of the system). Cows were granted milking permission after 4.5 hours from previous milking, unless a milking failure occurred, in which case cows would be granted permission to be milked again immediately. In general, for any particular cow, when the time elapsed since last milking was more than 12 hours during the day, that cow would be fetched and forced to visit the AMS. The milking status of each cow was checked at 06:00, 12:00, 18:00, and 22:30 hours daily. Cows with more than 12 hours since last milking were fetched only at these times.

Water and a partially mixed ration were available ad libitum. The frequency delivery of partial mixed ration was three times a day (at 06:30, 10:30 and 16:30). The partially mixed ration was a composed of $20.0 \mathrm{~kg}$ of corn silage, $15.0 \mathrm{~kg}$ of alfalfa haulage, $1.0 \mathrm{~kg}$ of grass hay, $2.0 \mathrm{~kg}$ of grain molasses, $1.6 \mathrm{~kg}$ of concentrates (ground grain), $0.8 \mathrm{~kg}$ of soybean meal, $1.0 \mathrm{~kg}$ of sunflower cake, $0.3 \mathrm{~kg}$ of energy protein concentrate, $0.06 \mathrm{~kg}$ of urea, and $0.22 \mathrm{~kg}$ of minerals, containing $940.2 \mathrm{VEM} / \mathrm{kg}$ of $\mathrm{DM}$ and $17.2 \% \mathrm{CP}$.

The farm was visited twice, 4 days apart, to collect 1 period of 3 complete days (each representing a 24-h period between 00:00 and 23:59 hours) of data. The data set consisted of 1,008 records of normal, uninterrupted milkings following normal, uninterrupted milkings. Visits to the AMS for milking and related production parameters were automatically recorded by the AMS computer system (T4C, Lely Industries N.V., Maassluis, the Netherlands). Deviating observations caused by registration errors were excluded from the data set. In total, 106 Holstein cows were observed with average lactation number of monitored cows was $1.7 \pm 0.1$ (means \pm SD) and average days in milk was $80.0 \pm 2.0$.

Derived statistics of the data, such as, daily milk yield per cow (kg), milk yield per milking $(\mathrm{kg})$, box-visiting time per milking (the time spent by every cow on milking processes in every milking, including entry in the AMS, udder cleaning, cluster attachment, sealing of teat, and exit) (min), milking time ( $\mathrm{min})$, milking interval (time between the beginning of 2 consecutive milkings) (h), average milk flow rate ( $\mathrm{kg} / \mathrm{min})$, maximum milk flow rate $(\mathrm{kg} / \mathrm{min})$, latency period milk flow (the interval from start of udder teat stimulation until the onset of milk ejection) (s). The data obtained in the study were analyzed in MS Excel program.

\section{Results and discussion}

\subsection{Milking frequency and milk production}

The system contributes to the formation in animals of a certain stereotype of behavioral reactions during the day. The daily distribution analysis of the number of milkings, depending on the time, showed that the cows are milked almost evenly throughout the day (Figure).

The average number of milkings ranged from 9.7 to 17.0 times per hour. If the day $(24 \mathrm{~h})$ is divided in three time periods (according to hours), then from 00:01 to 08:00 there were an average of 13.2 AMS visits, from 08:01 to $16: 00$ - 14.9 and from 16:01 to $24: 00-$ 13.9 visits. Thus, a little more activity of cows visiting the milking station can be observed in the daytime and evening. The results are consistent with other studies $[9,10]$. However, the average number of milkings in our studies was higher than in other studies. This is due to the fact that in our studies the minimum milking interval is 4.5 hours, in other studies this interval is 6.0 hours.

The main advantage of automated milking is to establish the frequency of milking, depending on the physiological state and milk production. There is abundant evidence that the rate of milk secretion is directly correlated with milking frequency, as a result of the mechanisms related to the local control of milk secretion [11]. Long intervals between milkings have been reported to decrease mammary blood flow [12] and down regulate the ability of udder to extract nutrients from the blood [13]. The results of studies showed that at a daily milk yield per cow of $22.0 \pm 0.6 \mathrm{~kg}$, the milking frequency was 2 times (13.5\% of the total number of milkings), $32.7 \pm 0.4 \mathrm{~kg}-3$ times $(57.2 \%), 37.7 \pm 0.6 \mathrm{~kg}-4$ times $(28.0 \%), 51.3 \pm 4.1 \mathrm{~kg}-5$ times $(1.3 \%)$. This is consistent with studies [14], where it was found, that the highest milking frequency of cows was in the first period of lactation. According to our research, at a 2 times frequency of milking, the daily milk yield per cow was significantly lower $(\mathrm{P}<0.001)$, than at 3,4 and 5 times milking. Cows with a 5 times frequency of milking a day showed the highest daily yield $(\mathrm{P}<0.001)$.

Thus, the main criterion for determining the frequency of milking is milk production, i.e. capacitive function of the breast. This result agreed with several researchers who have published on effect of milking frequency on milk yield [15-17]. However, other researchers have reported no increase in milk production related to increasing frequency of milking by AMS $[8,18]$. Cow-related factors, including stage of lactation, and parity, are also known to affect milking frequency in AMS [19].

Otherwise there is a tendency of milk yield per milking, so with an increase in the frequency of milking, the milk yield per milking decreases from $11.0 \pm 0.2 \mathrm{~kg}$ when visiting a milking session 2 times to $9.4 \pm 0.1 \mathrm{~kg}$ 
when visiting a milking station 4 times. Other studies have found, that high-yielding cows in AMS couple higher milking frequency with higher yield per milking, indicating that voluntary milking behavior and milk yield potential are both important factors to consider [20].

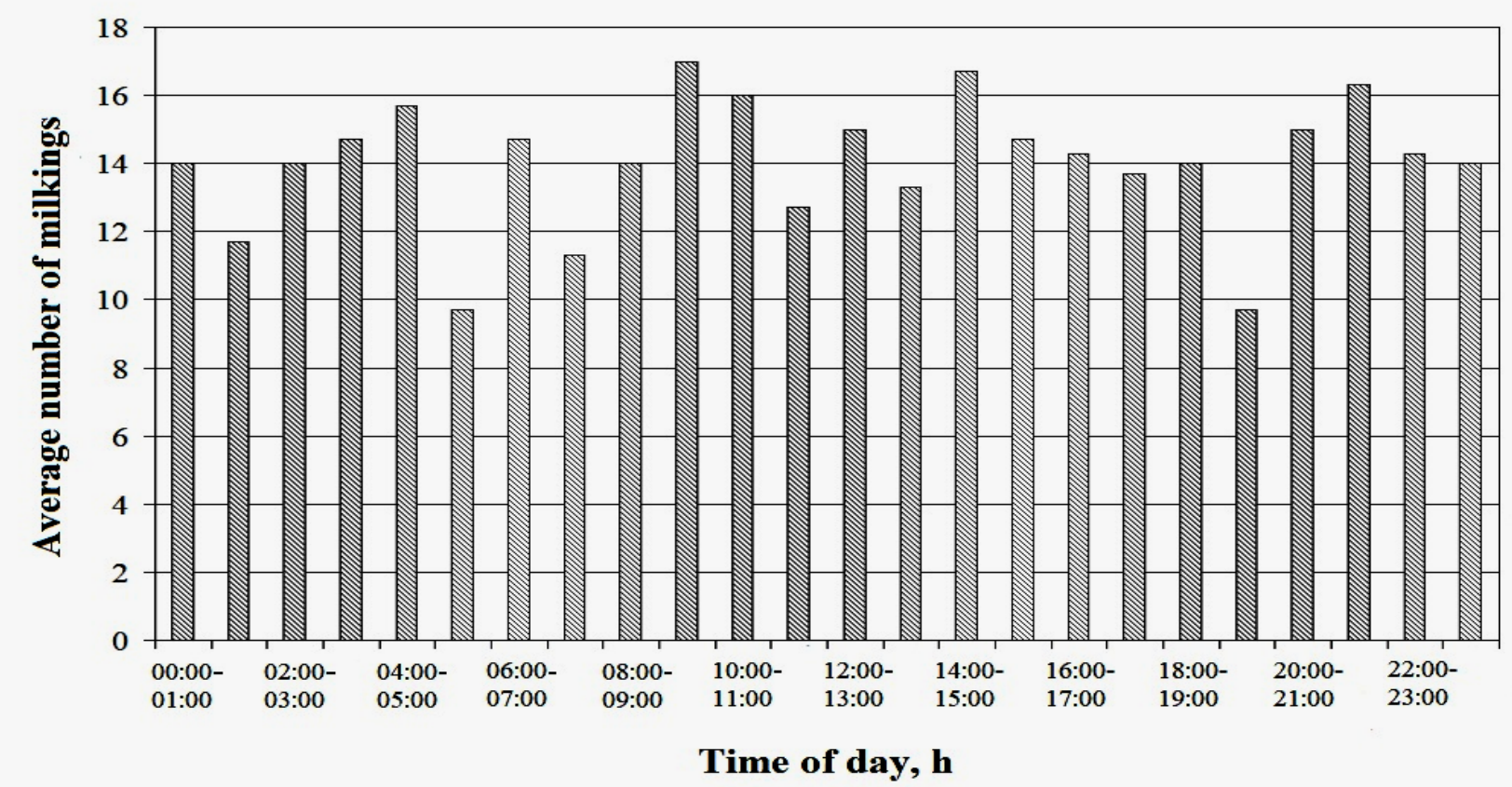

Fig. 1. Average number of visits/h during the entire study to the AMS by cows

\subsection{Milking intervals and functional properties of the udder}

With the change in the duration of the intervals between milking during the day, change the value of a milk yield per milking, the degree of filling of the mammary gland and the process of milk ejection. Milking cows at an optimal milking interval has the potential to increase milk yield [21]. Further, the effect of the interval on milk yield varies between herds as well as between individual cows [22]. Therefore, the analysis of the functional properties of the udder is important in studying physiological responses of dairy cows to milking. We have evaluated the influence of the milking intervals on the functional properties of the udder of cows (Table).

The results in Table show that it is possible to increase the daily milk yield by reducing the interval of milking $(\mathrm{P}<0.001)$. However, milk yield per milking has the opposite tendency and reaches the highest value at intervals between milkings of $9.00-10.49$ hours $11.8 \pm 0.13 \mathrm{~kg}(\mathrm{P}<0.001)$.

In these studies cows milking duration is determined by milk yield per milking and milk flow rate, which varies at different milking intervals. So, when selecting for cows with shorter milking durations, care is required to ensure that milk yield is not negatively affected, as milking time has been reported to be positively associated with milk yield [23, 24].

Table 1. The influence of the milking intervals $(n=1,008)$ on the milk productivity and functional properties of the udder of cows in AMS (mean $\pm \mathrm{SD})$

\begin{tabular}{|l|c|c|c|c|c|}
\hline \multirow{2}{*}{ Variable } & \multicolumn{5}{|c|}{ Milking interval, $\mathrm{h}$} \\
\cline { 2 - 6 } & $\begin{array}{c}4.50-5.99 \\
(\mathrm{n}=216)\end{array}$ & $\begin{array}{c}6.00-7.49 \\
(\mathrm{n}=227)\end{array}$ & $\begin{array}{c}7.50-8.99 \\
(\mathrm{n}=226)\end{array}$ & $\begin{array}{c}9.00-10.49 \\
(\mathrm{n}=247)\end{array}$ & $\begin{array}{c}10.50-11.99 \\
(\mathrm{n}=92)\end{array}$ \\
\hline Daily milk yield per cow, kg & $36.6 \pm 0.47$ & $35.1 \pm 0.48$ & $33.2 \pm 0.43$ & $31.9 \pm 0.44$ & $24.1 \pm 1.69$ \\
\hline Milk yield per milking, kg & $8.2 \pm 0.12$ & $9.8 \pm 0.14$ & $11.3 \pm 0.13$ & $11.8 \pm 0.13$ & $9.3 \pm 0.39$ \\
\hline Box-visiting time per milking, min & $6.35 \pm 0.11$ & $6.85 \pm 0.11$ & $7.48 \pm 0.14$ & $8.41 \pm 0.14$ & $8.19 \pm 0.80$ \\
\hline Milking time, min & $4.24 \pm 0.10$ & $4.83 \pm 0.10$ & $5.34 \pm 0.13$ & $6.10 \pm 0.12$ & $5.68 \pm 0.62$ \\
\hline Average milk flow rate, kg/min & $2.12 \pm 0.05$ & $2.21 \pm 0.05$ & $2.36 \pm 0.05$ & $2.11 \pm 0.04$ & $1.80 \pm 0.10$ \\
\hline Maximum milk flow rate, kg/min & $3.01 \pm 0.06$ & $3.22 \pm 0.07$ & $3.36 \pm 0.07$ & $3.18 \pm 0.05$ & $3.14 \pm 0.15$ \\
\hline Latency period milk flow, s: & & & & & \\
\hline Left front quarters (LF) & $15.7 \pm 0.50$ & $15.3 \pm 0.46$ & $15.2 \pm 0.47$ & $16.5 \pm 0.45$ & $22.8 \pm 0.72$ \\
\hline Right front quarters (RF) & $14.1 \pm 0.38$ & $13.9 \pm 0.31$ & $13.7 \pm 0.27$ & $15.6 \pm 0.38$ & $21.2 \pm 0.58$ \\
\hline Left rear quarters (LR) & $18.5 \pm 0.59$ & $16.8 \pm 0.47$ & $15.9 \pm 0.41$ & $17.9 \pm 0.49$ & $25.3 \pm 0.68$ \\
\hline Right rear quarters (RR) & $18.8 \pm 0.61$ & $16.9 \pm 0.53$ & $16.2 \pm 0.50$ & $17.6 \pm 0.46$ & $21.3 \pm 0.78$ \\
\hline
\end{tabular}


Measures of milk flow are also important in studying physiological responses of dairy animals to milking [25]. The average and maximum milk flow rates increased with an increase in the milking interval and reached the highest values in the interval of $7.50-8.99$ hours $2.36 \pm 0.05$ and $3.36 \pm 0.07 \mathrm{~kg} / \mathrm{min}$, respectively $(\mathrm{P}<0.01)$. However, with an increase in the milking intervals to $9.00-10.49$ hours, the average and maximum milk flow rates decreased to $2.11 \pm 0.04(\mathrm{P}<0.001)$ and $3.18 \pm 0.05(\mathrm{P}<0.05) \mathrm{kg} / \mathrm{min}$, and during the intervals between milkings $10,50-11.99$ hours - up to $1.80 \pm 0.20$ $(\mathrm{P}<0.001)$ and $3.14 \pm 0.25 \quad(\mathrm{P}<0.05) \quad \mathrm{kg} / \mathrm{min}$, respectively. Cows with a low indicator of maximum milk flow rate $(3.01 \pm 0.06 \mathrm{~kg} / \mathrm{min})$ had greater milk production $(36.6 \pm 0.47 \mathrm{~kg})$. This result is consistent with other studies [26]. A number of authors came to the conclusion that the milk yield is greatly influenced by the milk flow rate [27]. Nonetheless, comparison of animals for milk flowing speed is not trivial and should account for differences among animals in milk yield as well as other systematic environmental effects such as parity and stage lactation [28, 29].

The delay from start of milking until start of milk ejection decreased with increasing milking interval. Thus, with an increase in the milking interval from 4.50-5.99 to 7.50-8.99 hours, it was accompanied by a decrease in the latency period milk flow in the quarters of the udder: the left front (LF) from $15.7 \pm 0.50$ to $15.2 \pm 0.47 \mathrm{~s}$, right front $(\mathrm{RF})$ from $14.1 \pm 0.38$ to $13.7 \pm 0.27 \mathrm{~s}$, left rear $(\mathrm{LR})-$ from $18.5 \pm 0.59$ to $15.9 \pm 0.41 \mathrm{~s}$ and right rear $(\mathrm{RR})-$ from $18.8 \pm 0.61$ to $16.2 \pm 0.50$ s. However, when the milking interval reached 9.00-10.49 and 10.50-11.99 hours, the latency period milk flow increased in quarters of the udder: LF from $16.5 \pm 0.45$ to $22.8 \pm 0.72 \mathrm{~s}$, RF from $15.6 \pm 0.38$ to $21.2 \pm 0.58 \mathrm{~s}, \mathrm{LR}-$ from $17.9 \pm 0.49$ to $25.3 \pm 0.68 \mathrm{~s}$ and $\mathrm{RR}$ - from $17.6 \pm 0.46$ to $21.3 \pm 0.78 \mathrm{~s}$.

Thus, with a decreasing degree of udder/quarter filling, there is an increase in the delay from the start of milking until commencement of milk ejection. This is consistent with studies [30], where it was found, udder fill is low, such as during late lactation or after short milking intervals, the interval from start of teat stimulation until the onset of milk ejection is greater compared with when udder fill is high. We found that an increase in the latent period of milk flow at high milking intervals (9.00-10.49 and 10.50-11.99 h) did not affect milk yield per milking, but only caused a long course of milk removal, as shown by elevated milking duration $(6.10 \pm 0.12$ and $5.68 \pm 0.62 \mathrm{~min})$ and reduced average milk flow rate $(2.11 \pm 0.04$ and $1.80 \pm 0.10 \mathrm{~kg} / \mathrm{min})$.

These data show the effect of the milking intervals on commencement and course of milk ejection. This relationship has to be considered in AMS, since the delayed milk ejection at extended milking intervals will affect the efficiency of the use of AMS.

\section{Conclusion}

Results from the current study highlight the effect of the frequency and intervals of milking on milk productivity and functional properties of the cows'udder in AMS. The fact that cows with a higher milking frequency in AMS exhibit faster higher milk productivity was confirmed. Different milking intervals also affect milk production. In this case, the study of the functional properties of the udder of cows can be useful in choosing a strategy to optimize the efficiency of the use of AMS.

\section{Acknowledgments}

The authors acknowledge Ildar Galimullin for his the technical advice during data collection in the farm "Mukhametshin Z.Z." (Sabinsky district, Republic of Tatarstan, Russia).

\section{References}

1. C. Hallén-Sandgren, U. Emanuelson, Proc. 56th Natl. Mastitis Counc. Ann. Mtg., 61-68 (2017)

2. A. Laurs, J. Priekulis, Agricult. Engineer. Res. Papers, 45(2), 85-92 (2013)

3. J.A. Deming, R. Bergeron, K.E. Leslie, T.J. De Vries, J. Dairy Sci., 96, 344-351 (2013)

4. V.E. Scott, P.C. Thomson, K.L. Kerrisk, S.C. Garcia, J. Dairy Sci., 97, 1481-1490 (2014)

5. C. Carlstrom, G. Pettersson, K. Johansson, E. Strandberg, H. Stalhammar, J. Philipsson, J. Dairy Sci., 96, 5324-5332 (2013)

6. D.R. Sharipov, I.Sh. Galimullin, Scientific notes of Kazan Bauman State Academy of Veterinary Medicine, 236(IV), 208-212 (2018)

7. H. Hogeveen, K. Heemskerk, E. Mathijs, A Better Understanding of Automatic Milking, 56-61 (2004)

8. L. Gygax, I. Neuffer, C. Kaufmann, R. Hauser, B. Wechsler, J. Dairy Sci., 90, 4265-4274 (2007)

9. H. Unal, H. Kuraloglu, 14th Int. Sci. Conf., 100-105 (2015)

10. H. Unal, H. Kuraloglu, M. Koyuncu, K. Alibas, The J. of Anim. \& Plant Sci., 27(5), 1454-1463 (2017)

11. C.H. Knight, M. Peaker, C.J. Wilde, Rev. Reprod., 3, 104-112 (1998)

12. E. Delamaire, J. Guinard-Flament, J. Dairy Sci., 89, 3439-3446 (2006)

13. E. Delamaire, J. Guinard-Flament, J. Dairy Sci., 89, 2007-2016 (2006)

14. S. König, F. Köhn, K. Kuwan, H. Simianer, M. Gauly, J. Dairy Sci., 89, 3636-3644 (2006)

15. M. Kuczaj, J. Pres, R. Bodarski, R. Kupczynski, T. Stefaniak, Medycyna Weterynaryjna, 66(1), 32-36 (2010)

16. J.A. Jacobs, J.M. Siegford, J. Dairy Sci., 95, 2227-2247 (2012)

17. J.B. Wright, E.H. Wall, T.B. McFadden, J. Anim. Sci., 91, 195-202 (2013) 
18. F. Abeni, M.G. Terzano, M. Speroni, L. Migliorati, M. Capelletti, F. Calza, L. Bianchi, G. Pirlo, J. Dairy Sci., 91, 3372-3384 (2008)

19. M. Nixon, J. Bohmanova, J. Jamrozik, L.R. Schaeffer, K. Hand, F. Miglior, J. Dairy Sci., 92, 3422-3430 (2009)

20. P. Lovendahl, M.M.G. Chagunda, J. Dairy Sci., 94, 5381-5392 (2011)

21. G.E. Dahl, R.L. Wallace, R.D. Shanks, D. Lueking, J. Dairy Sci., 87, 882-885 (2004)

22. G. Andre, P.B.M. Berentsen, B. Engel, C.J.A.M. De Koning, A.G.J.M. Oude Lansink, J. Dairy Sci., 93, 942-953 (2010)

23. K.A. Gray, F. Vacirca, A. Bagnato, A.B. Samoré, A. Rossoni, C. Maltecca, J. Dairy Sci., 94, 960-970 (2011)
24. A.B. Samore, S.I. Roman-Ponce, F. Vacirca, E. Frigo, F. Canavesi, A. Bagnato, C. Maltecca, J. Dairy Sci., 94, 4081-4089 (2011)

25. P.G. Marnet, B.C. McKusick, Livest. Prod. Sci., 70, 125-133 (2001)

26. A. Bagnato, A. Rossoni, C. Maltecca, D. Vigo, S. Ghiroldi, Ital. J. Anim. Sci., 2(1), 46-48 (2003)

27. M. Bogucki, A. Sawa, I. Kuropatwinska, Acta Agricult. Scandinav., Section A - Ani. Sci., 67, 66-70 (2017)

28. D.P. Berry, B. Coughlan, B. Enright, S. Coughlan, M. Burke, J. Dairy Sci., 96, 5943-5953 (2013)

29. R. Miseikiene, S. Tusas, I. Cetinkaya, G. Gerulis, Veterinar. ir zootechn., 63(85), 62-65 (2018)

30. R.M. Bruckmaier, M. Hilger, J. Dairy Res., 68, 369-376 (2001) 